\title{
Correction to: Systematic review and meta-analysis of public hospital efficiency studies in Gulf region and selected countries in similar settings
}

\author{
Ahmed D. Alatawi ${ }^{1,2^{*}}$ (D) Sayem Ahmed ${ }^{1,3,4}$, Louis Niessen ${ }^{1,5,6}$ and Jahangir Khan 1,3,4
}

\section{Correction to: Cost Eff Resour Alloc (2019) 17:17} https://doi.org/10.1186/s12962-019-0185-4

Please note that following publication of the original article [1], two errors have been flagged by the authors.

Firstly, the article has been processed with the wrong article type: it is not a 'Review', but rather a 'Research article'.

Secondly, the initial of the corresponding author's middle name is missing in the original article; please see the corrected name in the author list of this Correction.

\section{Author details}

${ }^{1}$ Health Economics Group, Department of Clinical Sciences, Liverpool School of Tropical Medicine, LSTM, Room 1966-215-206, Pembroke Place, Liverpool L3 5QA, UK. ${ }^{2}$ Department of Clinical Pharmacy, College of Pharmacy, Al-Jouf University, 2014, King Khaled Road, Sakakah, Saudi Arabia. ${ }^{3}$ Health Economics and Financing Research Group, Health System and Population Studies Division, International Centre for Diarrhoeal Disease Research, Bangladesh (icddr,b), Dhaka, Bangladesh. ${ }^{4}$ Health Economics and Policy Research Group, Department of Learning, Informatics, Management and Ethics (LIME), Karolinska Institute, Stockholm, Sweden. ${ }^{5}$ Division of Health Sciences, University of Warwick, Warwick, UK. ${ }^{6}$ Department of International Health Systems, Johns Hopkins Bloomberg School of Public Health, Baltimore, USA.

Published online: 07 February 2020

The original article can be found online at https://doi.org/10.1186/s1296 2-019-0185-4.

*Correspondence: Ahmed.alatawi@lstmed.ac.uk

${ }^{1}$ Health Economics Group, Department of Clinical Sciences, Liverpool

School of Tropical Medicine, LSTM, Room 1966-215-206, Pembroke Place, Liverpool L3 50A, UK

Full list of author information is available at the end of the article

(c) The Author(s) 2020. This article is licensed under a Creative Commons Attribution 4.0 International License, which permits use, sharing, adaptation, distribution and reproduction in any medium or format, as long as you give appropriate credit to the original author(s) and the source, provide a link to the Creative Commons licence, and indicate if changes were made. The images or other third party material in this article are included in the article's Creative Commons licence, unless indicated otherwise in a credit line to the material. If material is not included in the article's Creative Commons licence and your intended use is not permitted by statutory regulation or exceeds the permitted use, you will need to obtain permission directly from the copyright holder. To view a copy of this licence, visit http://creativecommons.org/licenses/by/4.0/. The Creative Commons Public Domain Dedication waiver (http://creativecommons.org/publicdomain/zero/1.0/) applies to the data made available in this article, unless otherwise stated in a credit line to the data.

\section{Reference}

analysis of public hospital efciency studies in Gulf region and selected countries in similar settings. Cost Eff Resour Alloc. 2019;17:17. https://doi. org/10.1186/s12962-019-0185-4.

\section{Publisher's Note}

Springer Nature remains neutral with regard to jurisdictional claims in published maps and institutional affiliations. 